Stefan Zabierowski

Uniwersytet Śląski

zabierowski@tlen.pl

\title{
„Najmniej antypatyczną jest mi Austria” (Memoriał Josepha Conrada-Korzeniowskiego w sprawie polskiej z roku 1914)
}

\begin{abstract}
"Austria Is the Least Awful to Me" (Joseph Conrad-Korzeniowski’s 1914 Note on the Polish Problem)

Abstract: The article attempts at a presentation and an interpretation of a relatively unknown text by Joseph Conrad, namely, his Memoriat w sprawie polskiej [Note on the Polish Problem], written in Zakopane in 1914. The author of this article by interpreting the text of that document proves that it was created - to a great extent - under the influence of trialist conceptions of Galician conservatives, predominantly, an eminent lawyer from Kraków, Ph.D. Teodor Kosch.
\end{abstract}

Keywords: Joseph Conrad-Korzeniowski, World War I, Polish problem

Streszczenie: Artykuł stanowi próbę prezentacji i interpretacji stosunkowo mało znanego tekstu Conrada, jego Memoriatu w sprawie polskiej, napisanego w Zakopanem w roku 1914. Autor artykułu, interpretując treść owego dokumentu, dowodzi, że powstał on w dużej mierze pod wpływem trialistycznych koncepcji konserwatystów galicyjskich, a przede wszystkim wybitnego adwokata krakowskiego, doktora Teodora Koscha.

Słowa kluczowe: Joseph Conrad-Korzeniowski, pierwsza wojna światowa, sprawa polska

Jednym z ważnych tekstów Josepha Conrada dotyczącym spraw polskich jest napisany w Zakopanem, w początkach października 1914 roku - Memoriat $w$ sprawie polskiej. Jedynym informatorem o genezie tegoż dokumentu był krakowski adwokat doktor Teodor Kosch (1872-1964). Kosch opisywał 
okoliczności powstania owego Memoriatu dwukrotnie. Pierwszy raz w roku 1934 w szacownym konserwatywnym dzienniku krakowskim „Czas”, wówczas przytoczył też in extenso treść owego dokumentu, oraz powtórnie w roku 1960 na łamach „Tygodnika Powszechnego”, pisma, które zawsze okazywało Conradowi życzliwe zainteresowanie ${ }^{1}$.

Postawmy pytanie: $\mathrm{w}$ jakich okolicznościach doszło do spotkania wybitnego pisarza angielskiego ze znanym krakowskim adwokatem?

W roku 1914 Conrad postanowił odwiedzić ziemie polskie po wieloletniej nieobecności, korzystając z zaproszenia swoich polskich młodych przyjaciół, poznanych dwa latach wcześniej - Otolii i Józefa Hieronima Retingerów ${ }^{2}$. Formalnie zapraszała pisarza i jego bliskich właścicielka majątku Goszcza pod Krakowem, ale już w zaborze rosyjskim, Emilia Zubrzycka, matka Otolii. Podróż do Polski stała się w życiorysie Conrada, jego żony i synów, doniosłym wydarzeniem. Tak o tym pisał:

Cieszyłem się na myśl, że pokażę moim bliskim, jak wygląda życie na polskiej wsi, że miasto, w którym chodziłem do szkoły, odwiedzimy, zanim moi synowie za bardzo dorosną i, zdobywając każdy własną przeszłość, stracą niekłamane zaciekawienie moją przeszłością

Przed opuszczeniem Anglii, na wiosnę 1914 roku, Conrad udzielił wywiadu przedstawicielowi warszawskiego „Tygodnika Ilustrowanego” Marianowi Dąbrowskiemu. W wywiadzie tym padły ważne sformułowania określające stosunek Conrada do zaborców Polski, nieistniejącej wówczas na mapie Europy:

Do Prusaków mam wyrozumowaną nienawiść za ich eksterminacyjną politykę i za pogardę dla nas. Najmniej antypatyczną jest mi Austria. Właściwie, to dziwne, mam sympatię dla dynastii, coś ciekawego zaiste. Miałem nawet wstąpić jako dziecko do szkoły kadetów morskich w Polí.

Conrad wraz z żoną Jessie, synami Borysem (16 lat) i Johnem (8 lat), w towarzystwie i pod opieką obojga Retingerów wyruszył z Anglii do Polski 25 lipca 1914 roku. Najpierw odbyli podróż drogą morską z Harwich do Hamburga,

${ }^{1}$ T. Kosch, Memoriat Conrada (Korzeniowskiego) o sprawie polskiej w czasie wielkiej wojny, „Czas” 1934, nr 89; tenże, Powrót Conrada do Anglii, „Tygodnik Powszechny” 1960, nr 30.

2 O związkach Conrada z Retingerem istnieje wiele opracowań. Por. S. Zabierowski, Polska misja Conrada, Katowice 1984; O. Terlecki, Kuzynek diabta, Kraków 1988; J. Pomian, Józef Retinger. Życie i pamiętniki „szarej eminencji”, Warszawa 1990; B. Podgórski, Józef Retinger. Prywatny polityk, Kraków 2013.

${ }^{3}$ J. Conrad, Jeszcze raz w Polsce [w:] tegoż, O życiu i literaturze, tłum. M. Boduszyńska-Borowikowa, J. Miłobędzki, Warszawa 1974, s. 96.

${ }^{4}$ M. Dąbrowska, Rozmowa zJ. Conradem [w:] M. Dąbrowska, Szkice o Conradzie, wstęp, red., przyp. E. Korzeniewska, Warszawa 1974, s. 45. 
stamtąd pociągiem przez Berlin i Wiedeń do Krakowa, do którego przybyli 28 lipca 1914 roku wieczorem i zatrzymali się w wytwornym „Grand Hotelu", przy ulicy Sławkowskiej.

Powiedzmy od razu - trudno było o wybór gorszego terminu na odwiedziny Polski. Bowiem stało się tak, że w ową planowaną atrakcyjną podróż wdarła się brutalnie Wielka Historia. Przypomnijmy stosowne fakty.

28 czerwca 1914 roku w bośniackim Sarajewie został zastrzelony arcyksiążę Franciszek Ferdynand Habsburg, a miesiąc później cesarz austriacki Franciszek Józef I Habsburg wypowiedział wojnę królestwu Serbii, (...) Rosja uznała, że nie może dopuścić do zniszczenia Serbii i do triumfu wrogiej jej austro-węgierskiej (c.k.) monarchii, przeto dwa dni później car Mikołaj II Romanow podpisał ukaz o powszechnej mobilizacji (...). 1 sierpnia Rzesza wypowiedziała wojnę Rosji, a 3 sierpnia Francji. W nocy z 4 na 5 sierpnia Wielka Brytania znalazła się w stanie wojny z Rzeszą, a 6 sierpnia Austro-Węgry z Rosją. (...) Rozpoczęła się wojna Dwuprzymierza (Rzesza i Austro-Węgry) z Trójporozumieniem (Rosja, Francja i Wielka Brytania) $)^{5}$.

Tak więc nagle Conrad z rodziną znalazł się w oku cyklonu. Z turysty stał się obywatelem wrogiego wobec Austro-Węgier państwa. W tej sytuacji postanowił skrócić pobyt w Krakowie, gdzie wraz z żoną i synami zwiedzał miasto i zapewne za radą i z pomocą Retingera, który nieźle orientował się w wydarzeniach politycznych - postanowił trudny czas przeczekać w Zakopanem, gdzie miał dalszą rodzinę ${ }^{6}$. Tak pisał o tym 1 sierpnia w liście do swego przyjaciela, Johna Galsworthy'ego:

Złapała nas tu mobilizacja. Jeszcze przez trzy dni będą kursowały pociągi dla ludności cywilnej; ale z Jessie, która jest taką inwalidką, i z Jackiem, który czuje się niezbyt dobrze (gorączka), nie śmiem ryzykować koszmarnej wojennej wędrówki. Tak więc przynaglany i namawiany, i po dłuższym (24 godz.) namyśle, zdecydowałem się wywieźć siebie i cały nieszczęsny szczep do Zakopanego (w górach, okoto 4 godzin koleją stąd), poza teren wszelkich możliwych działań wojennych. Wolę być raczej unieruchomiony tutaj, gdzie mam przyjaciół, niż próbować wydostać się i utknąć w jakimś miasteczku niemieckim, pomiędzy armiami .

Conradowie przybyli do Zakopanego w pierwszych dniach sierpnia 1914 roku i najpierw zatrzymali się w pensjonacie „Stamary”. W lecie Zakopane, nazywane „letnią stolicą Polski”, gromadziło Polaków ze wszystkich trzech zaborów.

\footnotetext{
5 A. Chwalba, Wielka wojna Polaków 1914-1918, Warszawa 2018, s. 9-10.

${ }^{6}$ J. Pomian, dz. cyt., s. 40.

7 J. Conrad, Listy, tłum. H. Carroll-Najder, wyb., oprac. Z. Najder, Warszawa 1968, s. 341.
} 
Podobnie było i w roku 1914. O pobycie Conrada w pensjonacie „Stamary” wspominał po latach lekarz i malarz amator dr Kazimierz Górski. Pisał on:

Z Conradem spotkałem się w Zakopanem w pierwszych dniach sierpnia $1914 \mathrm{r}$. Do Zakopanego przybyłem na kilka dni przedtem na letni wypoczynek z najbliższą moją rodziną. Wojna zaskoczyła mnie tam, jak wielu innych Polaków, obywateli rosyjskich, ale nie spieszyłem się z powrotem do domowego ogniska, nęciła mnie sposobność przeżycia wielkich historycznych wydarzeń w środowisku, które skupiało w owym czasie przedstawicieli najróżnorodniejszych odcieni myśli politycznej polskiej. Los sprzyjał moim zamiarom i jemu zawdzięczam spotkanie z Conradem ${ }^{8}$.

Mieszkając w pensjonacie "Stamary”, Conrad zetknął się ze swoim znajomym z Londynu, sędziwym Adamem Giełgudem, niegdyś pracownikiem brytyjskiego Ministerstwa Wojny, a także sekretarzem lorda Palmertsona. Panowie Giełgud, Górski i Conrad spotykali się prawie codziennie, by toczyć dyskusje na aktualne tematy polityczne. Po kilku dniach Conradowie przeprowadzili się do pensjonatu „Konstantynówka”, który prowadziły kuzynki Conrada - Aniela Zagórska matka i jej córka, również o imieniu Aniela, która z czasem stała się słynną tłumaczką Conrada na język polski.

W tym samym pensjonacie zamieszkał również, z żoną i maleńką córeczką, dr Teodor Kosch - wybitny przedstawiciel palestry krakowskiej. Prowadził sprawy majątkowe Ignacego Paderewskiego, Henryka Sienkiewicza, Stanisława Tarnowskiego czy kardynała Jana Puzyny. $Z$ naszego punktu widzenia najważniejszym jest fakt, że Kosch był zatrudniony w departamencie skarbowym Naczelnego Komitetu Narodowego', Conradowie i Koschowie, sąsiadując ze sobą, rychło zaprzyjaźnili się. Pobyt w Zakopanem stał się dla Conrada okazją do spotkania z wieloma wybitnymi przedstawicielami polskiego życia kulturalnego przebywającymi wówczas pod Tatrami. Conrad poznał pisarzy Stefana Żeromskiego, Tadeusza Nalepińskiego i Jerzego Żuławskiego - a także malarza Jana Rembowskiego ${ }^{10}$.

Conrad i jego bliscy pilnie śledzili sytuację polityczną i zmieniające się położenie na frontach. Później wspominał:

Trudno dać pojęcie o tym, jak paskudnie i niebezpiecznie wyglądały te sprawy dla nas tam, w górach. Belgia powalona i stratowana na śmierć. Francja ustępuje pod

${ }^{8}$ K. Górski, Moje spotkanie z Josephem Conradem [w:] Polskie zaplecze Josepha Conrada-Korzeniowskiego. Dokumenty rodzinne, listy, wspomnienia, red. Z. Najder, J. Skolik, tłum. H. Carroll-Najder, t. 2, Lublin 2006, s. 255.

9 J. Pachoński, Kosch Teodor [w:] Polski stownik biograficzny, t. 14, red. E. Rostworowski, Wrocław 1968-1969, s. 193-194.

10 A. Busza, Conrad's Polish Literary Background and Some Illustrations of the Influence of Polish Literature on His Work, „Antemurale” (Romae-Londinii) 1966, s. 201. 
coraz to nowymi ciosami, klęska militarna podobna do tamtej z 1870 roku. Anglia zaś wplątana w to nieszczęsne przymierze, jej wojska przeznaczone na ofiarę, naród w panice! Polskie gazety nie rozporządzały oczywiście innymi źródłami informacji poza niemieckimi. Nie wierzyliśmy naturalnie wszystkiemu, cośmy czytali, ale czasem niezmiernie trudno było reagować na to $\mathrm{z}$ dostateczną stanowczością ${ }^{11}$.

W czasie pobytu w Krakowie i Zakopanem Conrad miał okazję zainteresowania się działalnością Józefa Piłsudskiego ${ }^{12}$. Wspominała Aniela Zagórska córka:

Dla ówczesnego Komendanta Głównego miał wielką cześć i wielki entuzjazm. Ale nie wierzył w realną wartość legionowego czynu, myślał, że ta krew pójdzie na marne. Przyjechał do Polski - po latach przeszło dwudziestu - i znalazł się wśród przygotowań do zbrojnej walki o niepodległość, wśród okoliczności, które nasuwały mu pewne analogie ze wspomnieniami najwcześniejszego dzieciństwa (w 1863 r. Conrad miał sześć lat) - z klęską, żałobą, beznadziejnością ${ }^{13}$.

Tymczasem sytuacja Conrada i jego rodziny w Zakopanem zaczęła się komplikować. Bowiem w momencie przystąpienia Wielkiej Brytanii do wojny stał się on obywatelem wrogiego państwa, a jemu i jego rodzinie groziło internowanie, ale szczęśliwie do tego nie doszło. Wedle wspomnień Koscha, kiedy Conrad zwrócił się do Komendy Placu w Nowym Targu z prośbą o pozwolenie na wyjazd do Wiednia:

Urzędnik Polak wprost radził po przyjacielsku, że Conrad zrobi najmądrzej, jeżeli mając tu krewnych i przyjaciół przytai się i cicho przesiedzi. Jeżeli się władze o nim w sposób oficjalny dowiedzą, to grozi mu internowanie w głąb Austrii, nie wiadomo na jak długo ${ }^{14}$.

Tymczasem położenie Conrada i jego bliskich stawało się coraz trudniejsze. Zaczęło brakować pieniędzy, a nadzieja powrotu do Anglii coraz bardziej się oddalała. W tej sytuacji pisarz zwrócił się do ambasadora amerykańskiego w Wiedniu Frederica C. Penfielda, który sprawował opiekę nad obywatelami angielskimi w cesarstwie Austro-Węgier, z prośbą o wsparcie. Penfield zasilił Conrada pewną sumą pieniędzy i obiecał konkretną pomoc, pod warunkiem

11 J. Conrad, Jeszcze raz w Polsce, dz. cyt., s. 124.

12 Por. S. Zabierowski, O Conradzie i Pitsudskim, „Teksty Drugie” 2009, nr 3, s. 13-46.

13 A. Zagórska, Kilka wspomnień o Conradzie [w:] Polskie zaplecze..., dz. cyt., t. 2, s. 252.

${ }_{14}$ T. Kosch, Powrót Conrada do Anglii [w:] Polskie zaplecze..., dz. cyt., t. 2, s. 265. 
że pisarz osobiście przybędzie do Wiednia. Aby tak się stało, konieczna była zgoda Komendy Placu w Nowym Targu, ale ta - jak wiadomo - odmawiała. W tym momencie z pomocą pospieszył dr Kosch. Jak wspominał:

Skorzystałem do tego celu z pomocy bawiącego w tym czasie w Zakopanem dr Franciszka Kowalskiego, mego koncypienta. Dr Kowalski oświadczył, że jego przyrodnia siostra pozostaje w bliskich towarzyskich stosunkach z generałową Kuckową ${ }^{15}$, żoną komendanta miasta Krakowa. Uplanowaliśmy więc skorzystać z pomocy jego siostry. Plan się wyśmienicie udał. Dr Kowalski pojechał do Krakowa i opisał całą rozpaczliwą sytuację Conrada i jego rodziny, którzy przyjechali do Polski tylko na kilka tygodni i w związku z tym są pozbawieni środków do życia, ciepłych ubrań itd. Siostra dra Kowalskiego przedstawiła całą sytuację swej przyjaciółce tak plastycznie, iż ta wzruszona nieszczęsnym losem Conradów wyjednała od swego męża bilet następującej treści: „Józef Conrad Korzeniowski zamierza ze swą rodziną wyjechać do Wiednia. Z punktu widzenia wojskowego nie zachodzą żadne przeszkody. P.T. Władze są proszone zezwolić tej rodzinie na przejazd"16.

Tu dwa uzupełnienia. Nazwisko austriackiego generała brzmiało Karl Kuk i był on komendantem twierdzy Kraków. Tak więc droga do Wiednia stała otworem, choć - ze względu na transporty wojska - powrót do stolicy c.k. monarchii nie był prosty. Przed wyjazdem z Zakopanego Conrad, po licznych dyskusjach na tematy polityczne, postanowił sformułować pewne propozycje wyrażające interesy Polaków. Wspominał Kosch:

Wśród przygotowań do wyjazdu rozmawiał Conrad ze mną często o tym, że chciałby stać się pożytecznym w jakiś sposób dla sprawy polskiej. Mówił, że ma w Anglii wprawdzie niewielkie tylko koło przyjaciól, bo prowadzi życie zamknięte, ale ma przez tych przyjaciół kontakt z najwpływowszymi czynnikami i mógłby niejedno dobre zrobić przez samo zwrócenie uwagi na jakiś szczegół, którego tam nie znają. Niestety to, co słyszy dookoła, wydaje mu się beznadziejne i po prostu nie wie, co by mógł z tego, co słyszy, wycisnąć na pożytek sprawy polskiej. Prosił tedy: „Dajcie mi materiat!" 17.

W rezultacie tych rozmów z polskimi przyjaciółmi, przede wszystkim zaś - z Koschem, powiązanym z NKN - Conrad przygotował dokument, w którym naszkicował swoje poczynania, jakie planował podjąć po powrocie do Anglii. Warto w tym miejscu przypomnieć, że Conrad już wcześniej, niezależnie od twórczości literackiej, zajmował się też publicystyką polityczną. Na uwagę

15 Tak w oryginale.

16 T. Kosch, Powrót Conrada do Anglii, dz. cyt., s. 266-267.

17 Tenże, Memoriat Conrada (Korzeniowskiego) o sprawie polskiej w czasie wielkiej wojny [w:] Polskie zaplecze..., dz. cyt., t. 2, s. 261. 
zasługują tu przede wszystkim esej Autokracja i wojna z roku 1905, skreślony po klęsce Rosji carskiej w wojnie z Japonią i po pierwszych przejawach rewolucji rosyjskiej w 1905 roku, zamieszczony w periodyku „Fortnightly Review”. Później, w roku 1912 Conrad opublikował na łamach dziennika „The Times" artykuł Przysztość Konstantynopola. Oba te teksty te miały zdecydowanie antyrosyjską wymowę.

Ze względu na doniosłość zakopiańskiego dokumentu oraz ze względu na fakt, że jest on stosunkowo mało znany ${ }^{18}$, pozwolę sobie ten dokument przytoczyć in extenso:

W przekonaniu, że interesa europejskie mogą tylko [muszą być] uregulowane [nie tylko za pomocą Kongresu wszystkich państw] po ogólnym zawieszeniu broni przez Kongres wszystkich państw, moim zamiarem jest:

Ogólnie:

[Przynajmniej] Wznieść i przyzwyczaić publiczność w Anglii do tej myśli, że Polakom należy się legalne uznanie ich narodowości tak w państwach pokonanych, jak i w państwach zwycięskich.

Takiemu uznaniu, które będzie mieć legalną podstawę, wysokie moralne znacznie i praktyczne następstwa, Anglia sprzeciwić się nie będzie miała racji, a może być namówiona do popierania tej kwestii na gruncie najprostszej sprawiedliwości.

Szczegółowo zaś: popierać i rozwijać uczucie sympatii dla Austrii (która już w lipcu egzystowała i była wyrażona w paru dziennikach). Wskazać, że Anglia z Austrią kłótni osobistej nie miała i nie ma; dążyć do wytworzenia przychylnego nastroju opinii publicznej, tłumacząc, że polityka austriacka pod groźnym naciskiem Rosji była wynikiem ciężkiej konieczności, a wcale nie objawem jakiejś niesprawiedliwej ambicji w kierunku powiększenia terytorialnego - jednakże kładąc nacisk na to, że po wielu latach cierpliwej, przezornej i pokojowej polityki Austria ma prawo żądać nagrody za swe wysiłki w tej wojnie.

Będzie mi o to chodzić, by ten ostatni punkt jasno postawić, a to z tej racji: mam przekonanie, że w ciągu Kongresu będą się wytwarzać rozmaite kombinacje państwowe. Może więc się zdarzyć, że w ciągu pertraktacji dyplomatyczna podpora Anglii może być dla Austrii pożyteczną. Nie tyle przeciw Rosji naturalnie, choć w Anglii żadnej czułości dla Rosji nie ma, ale może być przeciw naciskowi sprzymierzeńca w kwestii podziału podbitego terytorium, tj. głównie ziem polskich.

Na takie propozycje dyplomatyczne Austrii można w Anglii przygotować opinię publiczną i umysły w sferach parlamentarnych; tak np. u naczelników partii robotniczej (Labour Party), przewodników [jak i wybitnych członków] partii

${ }_{18}$ Memoriał Conrada ukazał się, oprócz pierwodruku w „Czasie” (1934, nr 89), przedrukowany z rękopisu (z naniesieniem poprawek) w antologiach Conrad wśród swoich. Listy, dokumenty, wspomnienia, oprac. Z. Najder, Warszawa 1996, s. 277-279; Polskie zaplecze..., dz. cyt., t. 1, s. 91-92; w tłumaczeniu angielskim został zamieszczony w tomie: Joseph Conrad. Centennial Essays, red. L. Krzyżanowski, New York 1960, s. 123-125, 138-139. 
konserwatywnej, a także u kilku wybitnych [głównych] członków partii liberalnej i wpływowych dziennikarzy w obu obozach.

Argumentację moją będę opierał na dwóch faktach. 1 że Niemcy teraz nie mogą być pokonane. 2 że Anglia, choćby zostawiona sama sobie, będzie mogła [bardzo] Niemcom długo i dolegliwie dokuczać; gdyż o przewadze morskiej Anglii powątpiewania być nie może, a nastrój ducha tego narodu nie bardzo się zmienił od czasu wojen napoleońskich.

Słowo więc Anglii zawsze będzie mieć pewną powagę w ostatecznym uregulowaniu kwestii europejskich.

Opierając się tedy na tych dwóch faktach, zamierzam wskazać, że Niemcy (Prusy), choć nie mogą być pokonane, mogą jednakże być do pewnego stopnia poskromione; i że jedyną drogą do tego celu jest popierać wymagania Austrii, o ile te się tyczą ziem polskich, właśnie żeby powiększyć antygermańskie elementy w ustroju tego Cesarstwa dla równowagi przeciw prepotencji pruskiej w Europie. Gdyż na Rosję pod tym względem rachować Anglia nie może - najpierw dlatego, że Rosja będzie pokonaną, a po wtóre (i głównie) dlatego, że Prusy i Rosja mogą w niedalekiej przyszłości się skojarzyć.

Będzie więc w interesie Anglii (nawet na niekorzystnych dla siebie warunkach) popierać politykę polską Austrii, rozwinięcie ducha polskiego wrogiego dla Niemców w tej monarchii, która w istocie rzeczy nigdy ani politycznie, ani ekonomicznie niebezpieczną dla Anglii być nie może, a której instytucje parlamentarne, tak sympatyczne narodowi angielskiemu, są ze wszystkich europejskich państw najlepiej rozwinięte ${ }^{19}$.

Należy zaznaczyć, że ów Memoriat nie budził szczególnego zainteresowania badaczy. Krótką wzmiankę o tym dokumencie napotkamy w monografii Róży Jabłkowskiej. Pisała ona:

Dokument ten jest dowodem żywych zainteresowań pisarza problemami odzyskania przez Polskę niepodległości i pokazuje, w jaki sposób pragnął Conrad zainteresować tą sprawą opinię publiczną i czynniki rządowe w Anglii ${ }^{20}$.

Do Memoriatu zakopiańskiego nawiązał szwajcarski badacz Conrada Gustaw Morf, przebywający stale w Kanadzie, świetnie władający językiem polskim co wśród conradystów na Zachodzie było wyjątkiem - pisał on:

19 Memoriat Josepha Conrada-Korzeniowskiego w sprawie polskiej, październik 1914 [w:] Polskie zaplecze..., dz. cyt., t. 1, s. 91-92.

${ }^{20}$ Joseph Conrad Korzeniowski, oprac. R. Jabłkowska, Warszawa 1964, s. 367. 
na początku pierwszej wojny światowej będąc w Galicji, Conrad toczył wiele politycznych dyskusji z polskimi przyjaciółmi, żyjącymi w Zakopanem, a szczególnie z krakowskim prawnikiem dr Teodorem Koschem i panem Zajączkowskim biznesmanem. Esencja tych rozmów została wyłożona w Memorandum, które Conrad napisał w języku polskim. Osobliwy ten dokument został przekazany dr Koschowi ${ }^{21}$.

Znajomością zakopiańskiego dokumentu i omówieniem głównych myśli tego memoriału wykazał się w swej monumentalnej biografii Conrada-Korzeniowskiego Frederick R. Karl. Badacz ten akcentował proaustriackie sympatie pisarza i tłumaczył je faktem, że - w porównaniu z Prusakami czy Rosjanami zaborca austriacki był najłagodniejszy. Prócz tego był antyrosyjski, co nader odpowiadało Polakom ${ }^{22}$.

Ostatnio najszerzej skomentował tekst omawianego dokumentu w swojej biografii Conrada Zdzisław Najder, który dowodził, że Conrad:

Dla uporządkowania własnych myśli i ułatwienia narad spisał memoriał, w którym wyłożył zasady swojego przyszłego działania w Anglii na rzecz Polski. Celem naczelnym miało być przekonywanie społeczeństwa angielskiego, że prawa narodowe Polaków powinny zostać uznane zarówno przez państwa pokonane, jak i zwycięskie. Najlepsze widoki na przyszłość zdawał się Conrad upatrywać w dołączeniu ziem zaborów pruskiego i rosyjskiego do monarchii austro-węgierskiej, w której obrębie Polacy stworzyliby decydującą przeciwwagę dla wpływów niemieckich ${ }^{23}$.

Warto zwrócić uwagę, że pisząc to Memorandum, Conrad postawił przed sobą niezwykle trudne zadanie. Wywody jego opierały się na przeświadczeniu, że zakończeniem pierwszej wojny światowej będzie kongres, w którym państwa zwycięskie i państwa pokonane podejmą próbę wprowadzenia nowego ładu w Europie. Propozycja Conrada nawiązywała zapewne do kongresu wiedeńskiego z roku 1815, który - po wojnach napoleońskich - przywrócił względny porządek w Europie na prawie sto lat $\mathrm{i}-\mathrm{w}$ jakimś sensie - antycypowała ustalenia traktatu wersalskiego.

Przyjrzyjmy się zawartości owego dokumentu. Po pierwsze, Conrad domaga się uznania przez wszystkie państwa, które biorą udział w wojnie, że istnieje realnie naród polski i że naród ten ma niezbywalne prawa. Drugi postulat był o wiele bardziej skomplikowany i stanowił coś w rodzaju rozwiązywania kwadratury koła. Conrad spodziewał się bowiem, że pierwsza wojna światowa zakończy się swego rodzaju sytuacją patową. Wprawdzie Niemcy mają pokonaćznienawidzoną przez Conrada - Rosję, ale nie dadzą rady potędze Wielkiej

${ }^{21}$ G. Morf, The Polish Shades and Ghosts of Joseph Conrad, New York 1978, s. 104-105.

22 F.R. Karl, Joseph Conrad: The Three Lives, London 1979, s. 756 (przyp.).

23 Z. Najder, Życie Josepha Conrada-Korzeniowskiego, t. 2, Lublin 2006, s. 237. 
Brytanii. W takiej sytuacji w interesie Anglii, a także narodowości polskiej w Galicji jest popieranie przez rząd angielski cesarstwa Austro-Węgier, by wbić klin przeciwko sojuszowi Austro-Węgier i Niemiec. Dowodził w Memoriale:

Będzie więc w interesie Anglii (nawet w niekorzystnych dla siebie warunkach) popierać politykę polską Austrii, rozwinięcie ducha polskiego wrogiego dla Niemców w tej monarchii, która w istocie rzeczy nigdy ani politycznie, ani ekonomicznie niebezpieczną dla Anglii być nie może, a w której instytucje parlamentarne, tak sympatyczne narodowi angielskiemu, są ze wszystkich europejskich państw najlepiej rozwiniętee $e^{24}$.

Zwróćmy uwagę, że w Memoriale nie ma mowy o odzyskaniu przez Polskę niepodległego bytu państwowego, ale jedynie o wejściu możliwie dużego obszaru ziem historycznie polskich w obręb monarchii austro-węgierskiej, czyli państwa, w którym Polacy od roku 1869 uzyskali szeroką autonomię. Jak pisał historyk: „Druga połowa XIX w. były to bowiem czasy, kiedy spośród trzech zaborców jedynie zaborca austriacki stwarzał narodowości polskiej warunki do egzystencji”" ${ }^{25}$. Można postawić pytanie: skąd Conrad zaczerpnął takie pomysły?

Przecież przybywając do Krakowa, pisarz nie za bardzo orientował się w niuansach polityki polskiej. Wedle wspomnień Górskiego: „Na przygotowania Polaków do odegrania niezależnej roli w akcji wojennej zapatrywał się bardzo sceptycznie, polityków polskich nie znał, kierunki myśli politycznej były mu

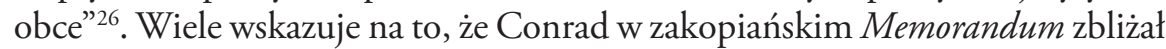
się do trialistycznych koncepcji monarchii austro-węgierskiej, polegających na tym, że trzecim ogniwem tego państwa - obok Austrii i Węgier - miała stać się Galicja, powiększona o ziemie zaboru rosyjskiego. Zwolennikami takiej właśnie koncepcji byli krakowscy konserwatyści wspierani przez demokratów. Andrzej Chwalba, charakteryzując owe ugrupowania, pisze:

Oczekiwali, że zbliżająca się wojna przyniesie powrót sprawy polskiej, dzięki sukcesowi państw centralnych. Do zachodnich aliantów nie mieli zaufania. Rosję uważali za głównego wroga polskich aspiracji, a Austro-Węgry za strategicznego sojusznika Polaków. Mieli nadzieję, że kiedy Austriacy odbiorą Rosji Królestwo Polskie z Warszawą, przyłączą je do Galicji, które razem będą stanowić trzeci człon państwa Habsburgów: Austro-Węgry - Polska. Stąd nieformalna nazwa obozu - trialiści ${ }^{27}$.

Wedle opinii Janusza Pajewskiego do poparcia tych koncepcji przychylał się cesarz Franciszek Józef I:

24 Tamże, s. 92.

25 S. Grodziski, Franciszek Józef I, Wrocław 1983, s. 127.

${ }^{26}$ K. Górski, dz. cyt, s. 256.

27 A. Chwalba, dz. cyt., s. 150. 
I chyba tylko cesarz Franciszek Józef, pomimo swej niechęci do jakichkolwiek zmian w ustroju państwa, zamyślał niekiedy o koronie polskiej, tzn. o przyłączeniu Królestwa, czy większej jego części do monarchii Habsburgów. Tym tłumaczyć można osobiste zainteresowanie cesarza Galicją, polityką namiestnika Bobrzyńskiego i pełen zaufania i sympatii stosunek sędziwego monarchy do polskiego uczonego i polityka. Tym tłumaczyć można udział Franciszka Józefa w planach odbudowy Polski kreślonych przez stańczyków w pierwszych tygodniach wojny ${ }^{28}$.

Pora postawić kolejne pytanie: kto ze znajomych zakopiańskich wpłynął w najwyższym stopniu na kształt propozycji politycznych Conrada-Korzeniowskiego zawartych w Memoriale?

Wydaje się, że osobą taką był przede wszystkim Kosch. Prawnik ten związany był ze środowiskiem konserwatystów galicyjskich. Kosch od roku 1897 należał do Stronnictwa Neokonserwatywnego i pełnił w nim funkcję sekretarza. Wszystko wskazuje na to, że ówczesne koncepcje austrofilskie Conrada i jego sympatie dla cesarza Franciszka Józefa miały swe źródło nie tylko w doświadczeniach galicyjskiej młodości, spędzonej we Lwowie i Krakowie, ale przede wszystkim w oddziaływaniu wybitnej jednostki, jaką był mecenas Kosch. Warto w tym miejscu dodać za biografem, że ten znany prawnik:

posiadał szeroką kulturę humanistyczną. Pisał pamiętniki i wspomnienia z podróży. (...) Zbliżył się do grupy artystów L. Wyczółkowskiego, J. Fałata, J. Mehoffera, W. Kossaka i K. Laszczki. (...) Zebrał kolekcję dzieł sztuki o wysokim poziomie (zrabowaną w dużej części przez gestapo). Zebrał również poważną bibliotekę ${ }^{29}$.

Człowiek tego formatu, posiadający szerokie kompetencje prawnicze, wyraziste poglądy polityczne, kontakty z wieloma wybitnymi osobistościami i wysoką kulturę humanistyczną mógł wpłynąć na przekonania Conrada dotyczące spraw polskich.

\section{4}

Wiele wskazuje na to, że po przybyciu do Wiednia Conrad starał się realizować - nakreślony w Zakopanem - plan działania. Warto w tym miejscu przypomnieć, że w owych latach liczni Polacy zajmowali ważne stanowiska w austro-węgierskim aparacie władzy. Jak informował Stanisław Grodziski: „Obok Agenora Gołuchowskiego juniora, ministra sprawa zagranicznych Austro-Węgier,

28 J. Pajewski, Odbudowa państwa polskiego 1914-1918, Warszawa 1985, s. 43.

29 J. Pachoński, Kosch Teodor, dz. cyt., s. 193. 
w rządzie Badeniego zasiadał Leon Biliński jako minister skarbu, Edward Ritner jako minister dla spraw Galicji”"

Nie dziwi fakt, że w czasie pobytu w Wiedniu - zapewne z rekomendacją Koscha - Conrad spotykał się z politykami Polakami, będącymi w służbie rządu austriackiego. Dowodzi tego treść jego listów przesyłanych adresatom w Polsce. Tak 18 października 1914 roku Conrad informował Koscha:

Pan Marian Biliński był łaskaw przyjść do mnie we wtorek. Miałem przyjemność i pożytek rozmawiać z nim przez parę godzin obszernie, wyczerpująco o kwestii polskiej w ogóle o sposobie jej postawienia ewentualnie przed Kongresem Europy, o nadziejach, obawach i możliwościach z nią związanych. (...) Dziś byłem u niego z wizytą godzinę, a może i dłużej, i rozmawialiśmy głównie o sposobie postawienia kwestii Polskiej w Anglii ${ }^{31}$.

W liście tym informował też Conrad o wizycie w ambasadzie amerykańskiej w Wiedniu. Przytoczmy stosowny fragment, przywołujący wiadomości przekazane Conradowi przez ambasadora Stanów Zjednoczonych: „Mówił mi, że Jego cesarska Mość nie tylko jest dobrze na zdrowiu, ale jakoby zdaje się, że bieżące wypadki podziałały rozbudzająco tak fizycznie, jak i umysłowo. No! Tym lepiej"32.

$\mathrm{Na}$ dwie kwestie warto tu zwrócić uwagę. Conrad spotkał się - zapewne za pośrednictwem ustosunkowanego dr. Koscha - w stolicy Austro-Węgier z wysokim urzędnikiem austriackim narodowości polskiej, dr. Marianem Bilińskim, radcą Oddziału wiedeńskiego Banku Związkowego i szefem Inspektoratu Poczty w Krakowie ${ }^{33}$. Marian Biliński miał brata Leona - pełniącego aktualnie funkcję austriackiego ministra skarbu. Byłoby nader niezręcznie, gdyby urzędujący minister spotykał się z wybitnym obywatelem wrogiego państwa, a takim był Conrad. Prawdopodobnie Marian Biliński odegrał rolę łącznika między Conradem i ministrem, jego bratem. Poza tym manifestacyjne zainteresowanie przez Conrada stanem zdrowia sędziwego Franciszka Józefa I mogło wynikać z programu pisarza, który bardzo liczył na propolską politykę tego cesarza, ale mogło też - ze względu na cenzurę listów w czasie wojny - świadczyć o lojalności nadawcy wobec władz we Wiedniu.

Będąc już na statku holenderskim, w drodze do Anglii, Conrad informował Mariana Bilińskiego:

Będę prosił komisarza okrętowego, by list ten rzucił na pocztę w Holandii; chodzi mi o to, żeby Pan wiedział, że nie zamierzam sprawy zasypiać. Spędzimy

${ }^{30}$ S. Grodziski, dz. cyt., s. 128.

31 J. Conrad do T. Koscha, 18.10.1914 [w:] Polskie zaplecze..., dz. cyt., t. 2, s. 94.

32 Tamże, s. 96.

33 Joseph Conrad Korzeniowski, dz. cyt., s. 366 (przyp. 1). 
w Londynie może cały tydzień właśnie dlatego, żeby się z ludźmi zobaczyć i rozmówić, a także i rozpatrzyć się w sytuacji ${ }^{34}$.

\section{5}

Jednak po przybyciu Conrada do Anglii okazało się - ze względu na sytuację polityczną i militarną - że polityczne pomysły zakopiańskie całkowicie straciły sens. Pisał Józef Ujejski o losach opcji proaustriackiej:

Prawdopodobniejsze zaś, że ta orientacja rychło bardzo z tamtej strony frontu utraciła dla niego aktualność, ustępując miejsca innej, tej mianowicie, która inspirowała „memorandum” napisane przez niego i przesłane do Foreign Office w lecie (w sierpniu) r. $1916^{35}$.

Najder przytoczył w swojej biografii złośliwy komentarz - niezwykle popularnego wówczas w Anglii pisarza - Arnolda Bennetta, który pozwolę sobie tu przypomnieć. Bennett zanotował w swoim dzienniku 4 listopada 1914 roku, że James B. Pinker:

widział dziś rano Conrada, który dopiero wrócił z austriackiej części Polski. Conrad ma niskie mniemanie o armii rosyjskiej i przyjechał do Anglii, by wpłynąć na opinię publiczną w celu uzyskania dobrych warunków dla Austrii. Też pomysł ${ }^{16}$

Pozostawiony w ręku dr. Koscha memoriał zakopiański całkiem się zdezaktualizował, ale dla badaczy stanowi ważne świadectwo przemian myśli politycznej Conrada-Korzeniowskiego. Bowiem stosunek autora Lorda Jima do jego pierwszej ojczyzny, Polski, podlegał w ciągu lat - daleko idącym - modyfikacjom ${ }^{37}$. Jako dziecko Konrad wychowany był w atmosferze żarliwego patriotyzmu, stał się ofiarą zaborcy rosyjskiego i razem z rodzicami został zesłany do Wołogdy, a później do Czernichowa. W tej ostatniej miejscowości utracił matkę, chorą na gruźlicę. Ofiarą tej samej choroby stał się ojciec, jeden z „palaczów ducha polskiego"38 - wedle określenia Żeromskiego. Z tym wszakże, że Apollo Korzeniowski zmarł już po powrocie ze zesłania, w Krakowie, otoczony szacunkiem rodaków. W wieku 17 lat Konrad - za zgodą swojego opiekuna - wuja

${ }^{34}$ J. Conrad do M. Bilińskiego, 9.11.1914 [w:] Polskie zaplecze..., dz. cyt., t. 2, s. 102.

35 J. Ujejski, O Konradzie Korzeniowskim, Warszawa 1936, s. 48.

${ }^{36}$ Z. Najder, dz. cyt., t. 2, s. 242.

37 Por. S. Zabierowski, Joseph Conrad-Korzeniowski i sprawa niepodlegtości Polski, „Arcana” 2017, nr 3.

${ }^{38}$ S. Żeromski, Joseph Conrad [w:] tegoż, Pisma literackie i krytyczne, red. S. Pigoń, Warszawa 1963, s. 131. 
Tadeusza Bobrowskiego - opuścił ziemie polskie na stałe, by służyć najpierw w marynarce handlowej francuskiej, a potem angielskiej. W roku 1886 uzyskał stopień kapitana marynarki i został obywatelem Wielkiej Brytanii. Wiele wskazuje na to, że w czasie służby na morzu Conrad doszedł do przekonania, iż los Polski jest definitywnie przesądzony. Tak pisał o losach rodzinnego kraju do swego przyjaciela, mieszkającego w Cardiff, Spirydiona Kliszczewskiego:

Wypadki rzucają cień, mniej lub bardziej zniekształcony, lecz dostatecznie ciemny, by wywołać złowróżbne obrazy pól bitwy w niedalekiej przyszłości: lecz wszystkie te zapowiedzi wielkich i decydujących wydarzeń pozostawiają mnie w stanie rozpaczliwej obojętności: bo jakiekolwiek mogą nastąpić zmiany w losach żyjących narodów, dla umarłych nie ma ani nadziei, ani zbawienia. Przeszliśmy już bramę ze słowami „lasciate ogni speranza”, wypisanymi ogniem i krwią a teraz brama zamknięta jest dla światła nadziei i nic nas już nie czeka prócz ciemności zapomnienia ${ }^{39}$.

Przyjazd do Polski w roku 1914, pobyt w Krakowie i Zakopanem, kontakty z wybitnymi rodakami, obszerne lektury w języku polskim w sposób radykalny zmieniły to nastawienie. Od tego czasu Conrad-Korzeniowski zaczął aktywne angażować się w sprawy swojej ojczyzny. Memorandum zakopiańskie stanowi pierwszy symptom tej zmiany. Po powrocie do Wielkiej Brytanii Conrad zmienił kierunek swej działalności na rzecz sprawy polskiej, ale bynajmniej jej nie zaniechał. Teraz zaczął liczyć na państwa ententy - przede wszystkim Anglię i Francję.

W roku 1916 w otoczeniu Conrada - po licznych przygodach, wśród których było zatrzymanie w więzieniu francuskim - pojawił się znów Retinger. Właśnie Retinger 15 sierpnia 1916 roku złożył wizytę w angielskim Ministerstwie Spraw Zagranicznych (Foreign Office), składając - opracowaną przez Conrada - Notę w sprawie polskiej. W dokumencie tym proponował autor Księcia Romana odbudowę państwa polskiego opartą na protektoracie angielsko-francuskim. Pisał:

Nic innego jak tylko bezpośredni, żywy, czynny udział dwu mocarstw zachodnich w utworzeniu nowej polskiej Wspólnoty Narodowej podczas pierwszych dwudziestu lat jej istnienia da Polakom dostateczną gwarancję bezpieczeństwa w ich pracy nad utworzeniem bytu narodowego ${ }^{40}$.

Tak kilka dni później komentował pisarz w liście do Retingera rozmowę z wysokim urzędnikiem angielskiego ministerstwa:

${ }^{39}$ J. Conrad do S. Kliszczewskiego, 13.10.1885 [w:] Polskie zaplecze..., dz. cyt., t. 2, s. $14-15$.

${ }^{40}$ J. Conrad, Nota w sprawie polskiej 1916 [w:] tegoż, Szkice polityczne, tłum. H. Carroll-Najder, W. Tarnawski, red. Z. Najder, Warszawa 1996, s. 68-69. 
Przypominam sobie, że na samym początku zwrócił Twoją uwagę, iż trudno jest Anglii dyskutować sprawy polskie gdziekolwiek poza Petrogradem: chociaż Anglicy chętnie usłuchaliby życzeń Polaków. Na Twoje konkretne pytanie - czy rząd brytyjski (w porozumieniu z Francja) aprobuje ogólnie biorąc pomysł protektoratu (potrójnego), odpowiedział: „niech Polacy przedstawią najpierw dokładnie sformułowane życzenie" 11 .

Jak wiadomo, propozycje Conrada zostały wówczas odrzucone. Jednak najważniejszym tekstem podejmującym problematykę polską jest obszerny esej Conrada z roku 1919 zatytułowany Zbrodnia rozbiorów. To wielka apologia pierwszej ojczyzny Konrada Korzeniowskiego, obejmująca zarówno jej historię, jak i problematykę najbardziej aktualną. W eseju tym Conrad kładł nacisk na przynależność Polski do Zachodu i wyrażał dumę z uzyskania przez nasz kraj niepodległego bytu państwowego. Pisał, że państwo polskie:

Przychodzi (...) na świat moralnie wolne, nie dzięki swoim cierpieniom, ale dzięki swojemu cudownemu odrodzeniu i zadawnionym prawom, wynikającym z zasług wobec Europy. Ani jeden z walczących na wszystkich frontach świata nie zginął świadomie za wolność Polski. Tej zaszczytnej sposobności odmówiono nawet jej własnym dzieciom. I dobrze się stało! ${ }^{42}$

Refleksem pobytu w Galicji stała się też, obecna w tekście owego szkicu, obrona działalności Piłsudskiego. Zacytujmy:

Z trudności teoretycznych i moralnych, w jakie wpędził polskie programy polityczne układ sojuszów międzynarodowych na początku wojny, wyłoniła się przynajmniej decyzja, aby Legiony Polskie, pokojowa organizacja w Galicji kierowana przez Piłsudskiego (który otrzymał później stopień generała, a obecnie, jak słyszymy, jest Naczelnikiem Rządu w Warszawie), wyruszyły do walki z Rosją. W gruncie rzeczy nie miało znaczenia, przeciwko któremu z uczestników Zbrodni skierowany będzie gniew Polaków. Trudno było wybierać między prymitywnymi i podłymi metodami rosyjskiego barbarzyństwa a wyrafinowaną i pogardliwą brutalnością powierzchownej i zmechanizowanej cywilizacji niemieckiej. Nie było w czym wybierać. Obie strony były nienawistne. Polacy korzystali oczywiście w swoich wysiłkach z tolerancyjnej postawy Austrii, która od lat patrzyła przez palce na półtajną organizację Legionów Polskich. Zresztą taką drogę wskazywały możliwości materialne $e^{43}$.

${ }^{41}$ J. Conrad do J.H. Retingera [w:] tegoż, Listy, dz. cyt., s. 358.

${ }^{42}$ J. Conrad, Zbrodnia rozbiorów 1919 [w:] tegoż, Szkice polityczne, dz. cyt., s. 58.

43 Tamże, s. 54. 
Jak widać wyrażane w 1919 roku poglądy Conrada-Korzeniowskiego na temat zaborców Polski niewiele zmieniły się w stosunku do opinii wypowiadanych w roku 1914 w wywiadzie udzielonym Marianowi Dąbrowskiemu.

Jest rzeczą godną uwagi, że Conrad uznał za stosowne przedrukować swoje teksty polityczne w tomie $O \dot{z} y c i u ~ i ~ l i t e r a t u r z e ~(1921)$. Nie znalazło się tam jednak Memorandum zakopiańskie. I stało się tak zapewne z kilku powodów. Po pierwsze dlatego, że zostało napisane w języku polskim, a Conrad przedrukowywał wyłącznie teksty angielskie, po wtóre dlatego, że był to tekst zdezaktualizowany, po trzecie wreszcie, że nie był to poprawny tekst, ale brulion.

Nie znaczy to jednak, że owo Memorandum zakopiańskie nie zasługuje na zainteresowanie. Dlaczego? Staraliśmy się tego dowieść w powyższym artykule.

\section{Bibliografia}

Busza A., Conrad's Polish Literary Background and Some Illustrations of the Influence of Polish Literature on His Work, „Antemurale” (Romae-Londinii) 1966.

Chwalba A., Wielka wojna Polaków 1914-1918, Warszawa 2018.

Conrad J. do M. Bilińskiego, 9.11.1914 [w:] Polskie zaplecze Josepha Conrada-Korzeniowskiego. Dokumenty rodzinne, listy, wspomnienia, red. Z. Najder, J. Skolik, tłum. H. Carroll-Najder, t. 2, Lublin 2006.

Conrad J. do S. Kliszczewskiego, 13.10.1885 [w:] Polskie zaplecze Josepha Conrada-Korzeniowskiego. Dokumenty rodzinne, listy, wspomnienia, red. Z. Najder, J. Skolik, tłum. H. Carroll-Najder, t. 2, Lublin 2006.

Conrad J. do T. Koscha, 18.10.1914 [w:] Polskie zaplecze Josepha Conrada-Korzeniowskiego. Dokumenty rodzinne, listy, wspomnienia, red. Z. Najder, J. Skolik, tłum. H. Carroll-Najder, t. 2, Lublin 2006.

Conrad J., Jeszcze raz w Polsce [w:] tegoż, Ożyciu i literaturze, tłum. M. Boduszyńska-Borowikowa, J. Miłobędzki, Warszawa 1974.

Conrad J., Listy, tłum. H. Carroll-Najder, wyb., oprac. Z. Najder, Warszawa 1968. Conrad J., Nota wsprawiepolskiej 1916 [w:] tegoż, Szkicepolityczne, tłum. H. Carroll-Najder, W. Tarnawski, red. Z. Najder, Warszawa 1996.

Conrad J., Zbrodnia rozbiorów 1919 [w:] tegoż, Szkice polityczne, tłum. H. Carroll-Najder, W. Tarnawski, red. Z. Najder, Warszawa 1996.

Conrad wśród swoich. Listy, dokumenty, wspomnienia, oprac. Z. Najder, Warszawa 1996.

Dąbrowska M., Rozmowa z J. Conradem [w:] M. Dąbrowska, Szkice o Conradzie, wstęp, red., przyp. E. Korzeniewska, Warszawa 1974.

Górski K., Moje spotkanie zJosephem Conradem [w:] Polskie zaplecze Josepha Conrada-Korzeniowskiego. Dokumenty rodzinne, listy, wspomnienia, red. Z. Najder, J. Skolik, tłum. H. Carroll-Najder, t. 2, Lublin 2006.

Grodziski S., Franciszek Józef I, Wrocław 1983.

Joseph Conrad. Centennial Essays, red. L. Krzyżanowski, New York 1960. 
Joseph Conrad Korzeniowski, oprac. R. Jabłkowska, Warszawa 1964.

Karl F.R., Joseph Conrad: The Three Lives, London 1979.

Kosch T., Memoriat Conrada (Korzeniowskiego) o sprawie polskiej w czasie wielkiej wojny, „Czas” 1934, nr 89.

Kosch T., Memoriat Conrada (Korzeniowskiego) o sprawie polskiej w czasie wielkiej wojny [w:] Polskie zaplecze Josepha Conrada-Korzeniowskiego. Dokumenty rodzinne, listy, wspomnienia, red. Z. Najder, J. Skolik, tłum. H. Carroll-Najder, t. 2, Lublin 2006.

Kosch T., Powrót Conrada do Anglii, „Tygodnik Powszechny” 1960, nr 30.

Kosch T., Powrót Conrada do Anglii [w:] Polskie zaplecze Josepha Conrada-Korzeniowskiego. Dokumenty rodzinne, listy, wspomnienia, red. Z. Najder, J. Skolik, tłum. H. Carroll-Najder, t. 2, Lublin 2006.

Memoriat Josepha Conrada-Korzeniowskiego w sprawie polskiej, październik 1914 [w:] Polskie zaplecze Josepha Conrada-Korzeniowskiego. Dokumenty rodzinne, listy, wspomnienia, red. Z. Najder, J. Skolik, tłum. H. Carroll-Najder, t. 2, Lublin 2006.

Morf G., The Polish Shades and Ghosts of Joseph Conrad, New York 1978.

Najder Z., Żcie Josepha Conrada-Korzeniowskiego, t. 2, Lublin 2006.

Pachoński J., Kosch Teodor [w:] Polski stownik biograficzny, t. 14, red. E. Rostworowski, Wrocław 1968-1969.

Pajewski J., Odbudowa państwa polskiego 1914-1918, Warszawa 1985.

Podgórski B., Józef Retinger. Prywatny polityk, Kraków 2013.

Pomian J., Józef Retinger. Żcie i pamiętniki „szarej eminencji”, Warszawa 1990.

Terlecki O., Kuzynek diabta, Kraków 1988.

Ujejski J., O Konradzie Korzeniowskim, Warszawa 1936.

Zabierowski S., Joseph Conrad-Korzeniowski i sprawa niepodlegtości Polski, „Arcana” 2017, nr 3.

Zabierowski S., O Conradzie i Pitsudskim, „Teksty Drugie” 2009, nr 3.

Zabierowski S., Polska misja Conrada, Katowice 1984.

Zagórska A., Kilka wspomnień o Conradzie [w:] Polskie zaplecze Josepha Conrada-Korzeniowskiego. Dokumenty rodzinne, listy, wspomnienia, red. Z. Najder, J. Skolik, tłum. H. Carroll-Najder, t. 2, Lublin 2006.

Żeromski S., Joseph Conrad [w:] tegoż, Pisma literackie i krytyczne, red. S. Pigoń, Warszawa 1963. 